\title{
APPLICATION OF CHEMOMETRIC ANALYSIS TO THE STUDY OF SNOW AT THE SUDETY MOUNTAINS, POLAND
}

\author{
ZASTOSOWANIE ANALIZ CHEMOMETRYCZNYCH \\ W BADANIACH ŚNIEŻNYCH W SUDETACH, POLSKA
}

\begin{abstract}
Snow samples were collected during winter 2011/2012 in three posts in the Western Sudety Mountains (Poland) in 3 consecutive phases of snow cover development, i.e. stabilisation (Feb 1st), growth (Mar 15th) and its ablation (Mar 27th). To maintain a fixed number of samples, each snow profile has been divided into six layers, but hydrochemical indications were made for each $10 \mathrm{~cm}$ section of core. The complete data set was subjected in the first run of chemometric data interpretation to Cluster Analysis as well as Principal Components Analysis. Further, Self-Organizing Maps, type of neutral network described by Kohonen were used for visualization and interpretation of large high-dimensional data sets. For each site the hierarchical Ward's method of linkage, squared Euclidean distance as similarity measure, standardized raw data, cluster significance test according to Sneath's criterion clustering of the chemical variables was done. Afterwards this grouping of the chemical variables was confirmed by the results from Principal Components Analysis. The major conclusion is that the whole system of three sampling sites four patterns of variable groupings are observed: the first one is related to the mineral salt impact; the second one - with the impact of secondary emissions and organic pollutants; next one - with dissolved matter effect and the last one - with oxidative influence, again with relation to anthropogenic activities like smog, coal burning, traffic etc. It might be also concluded that specificity of the samples is determined by the factors responsible for the data set structure and not by particular individual or time factors.
\end{abstract}

Keywords: snow chemistry, chemometric analysis, Principal Components Analysis, Sudety Moutains, Poland

\section{Introduction}

Snowpack is a specific "sink" of atmospheric pollution and for this reason its significance is particularly important for higher regions of the mountains where water and atmospheric pollutants in snow retention may last continuously for several months [1-3]. As

\footnotetext{
${ }^{1}$ Department of Climatology and Atmosphere Protection, Institute of Geography and Regional Development, University of Wroclaw, ul. A. Kosiby 8, 51-670 Wroclaw, Poland

${ }^{2}$ Department of Analytical Chemistry, Chemical Faculty, Gdansk University of Technology (GUT), ul. G. Narutowicza 11/12, 80-952 Gdańsk, Poland

${ }^{3}$ Chair of Analytical Chemistry, Faculty of Chemistry, University of Sofia, J Bourchier Blvd. 1, 1164 Sofia, Bulgaria

${ }^{4}$ Chair of Physical Chemistry, Faculty of Chemistry, University of Sofia, J Bourchier Blvd. 1, 1164 Sofia, Bulgaria

*Corresponding author: marek.blas@uwr.edu.pl
} 
long as a snow cover persists, it is subject to numerous processes: deposition of gaseous contaminants from the atmosphere to the snow surface without precipitation (dry deposition), fog/cloud droplets deposition on its surface; drifting and blowing snow; partial top-down or bottom-up thawing and related possible seepage of meltwater into the ground $[2,4,5]$. As a result, the chemistry of snow on the ground continually changes. If the snow does not melt, the overall contaminant load builds up with each succeeding snowfall. Release of pollutants from the snowpack and their transport to soil, ground, and surface waters occurs only during snow meltdown [5, 6]. Due to the longtime of snowpack formation and the large amount of water stored in the snowpack, it greatly influences the water income and pollutants deposition [1, 7-9]. The deposition rate of pollutants released from the snowpack is strictly related to the number and depth of thaw episodes. The most efficient release of pollutants occurs during the early phase of spring melt. The process leads to significant acidification of soil, areal and underground waters. This phenomenon has gained its name "ionic pulse" or "acid pulse" and is of great importance in mountain regions, where snowpack build-up and pollutants accumulation may last several months $[4,5,10,11]$.

The share of solid precipitation in an annual sum of precipitation in the Western Sudety Mountains is clearly related to their height above sea level and ranges from $27 \%$ at the foreland of the Karkonosze Mountains (Jelenia Gora) to $70 \%$ in the mountain ridge area. Average annual number of days with snow cover ranges from 94 at the altitude of $600 \mathrm{~m}$ a.s.l. to 170 at the altitude of $1100 \mathrm{~m}$ and exceeds 175 days on the level of $1500 \mathrm{~m}$ a.s.l. The biggest water equivalent in snow comes a few days after the snow cover reaches its maximum and ranges from $80 \mathrm{~mm}$ at the altitude of $600 \mathrm{~m}$ to $800 \mathrm{~mm}$ at the altitude of $800 \mathrm{~m}$. The water equivalent in concave forms in the upper slope and along the upper tree line can exceed $1000 \mathrm{~mm}$.

The problem of atmospheric pollution and the role of snow cover in polluting Polish mountain ecosystem has drawn attention since the mid 90ies of the XXth century when considerable deforestation in the Western Sudety Mountains was noted. The research area is under strong influence of the anthropogenic sources of pollutant emission to the atmosphere. $\mathrm{SO}_{2}$ emission is mainly connected with combustion of brown and hard coal with high sulphur content. It is used mainly by power plants, industry and households. Power plants and industry situated in the northern and north-western Czech Republic, in Saxony (Germany) and the Turow Power Plant in the south-western part of Poland are decisive for air pollution in the Western Sudety Mountains [10, 12-14].

The analysis of atmospheric precipitation and snow cover provides necessary data on precipitation water quality and real load of pollutants in the snow cover in the Western Sudety Mountains in Poland [12, 13]. Chemometric techniques applied in the phase of processing multi-parameter data sets enables to obtain information about actual correlations between the content of particular analits and the value of physical and chemical parameters for particular test beds $[15,16]$.

\section{Experimental}

\section{Sampling sites}

Snow samples were collected seasonally at 3 locations, over a period between January 2008 and March 2012 in the Western Sudety Mountains, where Polish, Czech Republic and German borders join together. It is the highest, north-eastern part of the Bohemian Massif 
which belongs to Hercynian European Highlands. In spite of relatively low altitudes (1000-1600 m a.s.1.), the Western Sudety Mts. are a significant orographic barrier for moist polar maritime air masses coming from the Atlantic Ocean. One of the atmospheric processes leading to precipitation formation or a regional enhancement of already existing precipitation is an ascent of sufficiently humid air masses forced by the morphology of a mountain barrier. Such an effect is clearly visible, especially in the westernmost part of the Sudety Mountains, where annual precipitation sums are typically 50-150\% higher than in the surrounding lowlands.

Two sampling sites represent convex landform in the Karkonosze Mountains and one a flat trough in the Izera Mountains (Table 1 and Fig. 1).
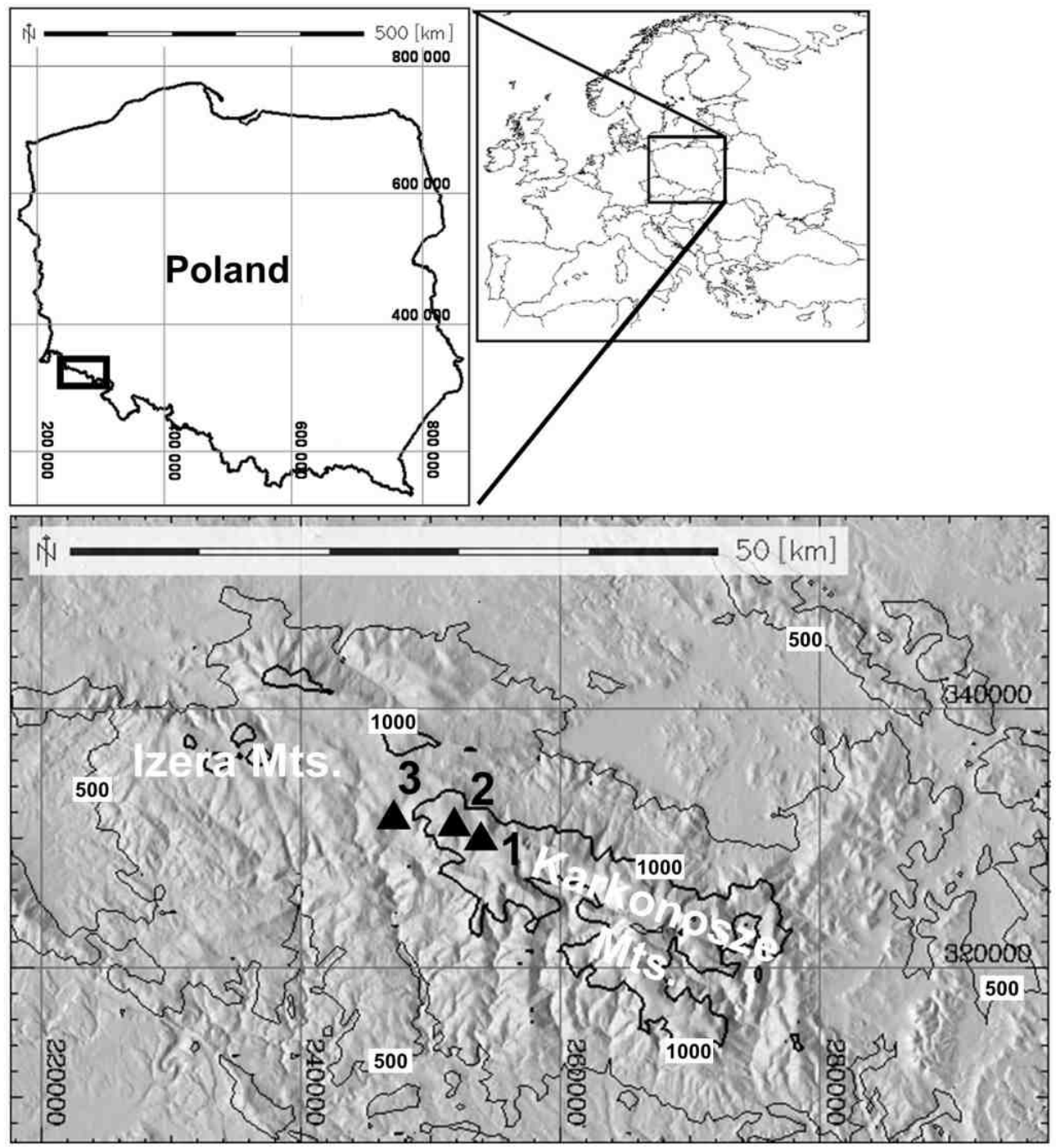

Fig. 1. Location of the sampling sites against larger background (Western Sudety Mountains), WGS84 coordinates used, 500 and $1000 \mathrm{~m}$ contour lines shown (sampling sites description - see Table 1) 
Table 1

Characteristics of the sampling sites (see also Fig. 1)

\begin{tabular}{|c|c|c|c|c|c|c|}
\hline No. & $\begin{array}{l}\text { Sampling } \\
\text { site }\end{array}$ & Code & $\begin{array}{l}\text { Altitude } \\
\text { [m a.s.l.] }\end{array}$ & $\begin{array}{c}\text { Landform } \\
\text { type }\end{array}$ & Site description & Pollution background \\
\hline 1 & $\begin{array}{c}\text { Szrenica } \\
\text { Karkonosze } \\
\text { Mts } \\
50^{\circ} 48^{\prime \prime} \mathrm{N} \\
15^{\circ} 31^{\prime \prime} \mathrm{E} \\
\end{array}$ & SZ & 1362 & $\begin{array}{l}\text { Convex, } \\
\text { mountain } \\
\text { ridge }\end{array}$ & \multirow{2}{*}{$\begin{array}{l}\text { Situated in the western part of the } \\
\text { Karkonosze Mts., the highest range of } \\
\text { the Sudety Mts with a mean altitude } \\
\text { of } 1200-1400 \mathrm{~m} \text { a.s.l. Stretch from } \\
\text { NW to SE for almost } 30 \mathrm{~km} \text {. The } \\
\text { main ridge falls steeply northward on } \\
\text { the Polish side and forms } \\
\text { a widespread "megaslope" about } \\
1000 \mathrm{~m} \text { high. The southern part, } \\
\text { extending on the Czech side, is } \\
\text { incised by deep valleys (i.e. Elbe) and } \\
\text { consists of numerous secondary } \\
\text { ridges. The top and around parts are } \\
\text { overgrown with dwarf mountain pine. } \\
\text { Below the upper part montane spruce } \\
\text { forests grow. }\end{array}$} & \multirow{3}{*}{$\begin{array}{l}\text { All sites are located in } \\
\text { one of the most } \\
\text { polluted mountainous } \\
\text { areas in Europe. The } \\
\text { Western Sudety Mts } \\
\text { are subjected to air } \\
\text { pollution emitted from } \\
\text { combustion of } \\
\text { sulphur-rich coal in } \\
\text { industrial regions on } \\
\text { the Polish, German and } \\
\text { Czech borderland. } \\
\text { During typical westerly } \\
\text { wind conditions they } \\
\text { are exposed to highly } \\
\text { polluted air from heavy } \\
\text { industry densely } \\
\text { situated at the distance } \\
\text { of tens to hundreds } \\
\text { kilometers on the } \\
\text { windward side of the } \\
\text { mountains. }\end{array}$} \\
\hline 2 & $\begin{array}{c}\text { Kamiennik } \\
\text { Karkonosze } \\
\text { Mts } \\
50^{\circ} 48^{\prime \prime} \mathrm{N} \\
15^{\circ} 30^{\prime \prime} \mathrm{E}\end{array}$ & KA & 1294 & $\begin{array}{l}\text { Convex, } \\
\text { mountain } \\
\text { ridge }\end{array}$ & & \\
\hline 3 & $\begin{array}{c}\text { Orle } \\
\text { Izera Mts } \\
50^{\circ} 78^{\prime \prime} \mathrm{N} \\
15^{\circ} 38^{\prime \prime} \mathrm{E}\end{array}$ & OR & 870 & Flat trough & $\begin{array}{l}\text { Relatively flat valley, situated in the } \\
\text { SE part of the Izera Mts. (valley } \\
\text { bottom } 800-840 \mathrm{~m} \text { a.s.l.; watershed } \\
\text { ridges } 890-1124 \text {; the plateau } \\
\text { surrounding the Izera Mts plateau } \\
\text { ca. } 400-500 \mathrm{~m} \text { a.sl.). Partly deforested } \\
\text { due to recent forest decline caused by } \\
\text { high rates of air pollution deposition. }\end{array}$ & \\
\hline
\end{tabular}

\section{Sampling procedure}

To calculate pollutant flux to the ground, both concentrations and precipitation volumes must be known. Monitoring stations for precipitation chemistry in locations dominated by snowfall yield inaccurate data because the methods used to measure snowfall volume and chemistry are not reliable. Many investigators have tried to improve a gauge design, its calibration, placement and wind correction. For precipitation and pollutant monitoring, especially in windy, mountain sites, the snow pits are the best alternative. Snow pit is a trench exposing a flat, vertical snow face from the snow surface to the ground (Fig. 2). It allows studying a snow water equivalent, as well as the characteristics of different layers of the snowpack that have developed as the snow has changed due to compaction and weather changes.

All of snow samples were collected continuously along a vertical profile of the snow cover with a resolution of $10 \mathrm{~cm}$ while wearing sterile overalls and gloves to minimize possible contamination (Fig. 2). All these samples were stored in sealed polyethylene bags and left to melt at the camp. After melting, snow samples were poured into pre-cleaned polyethylene bottles. To avoid losses of analytes to headspace, samplers were filled without air bubble. Then samples were transported to the laboratory and stored prior to analysis in the temperature of $4^{\circ} \mathrm{C}$. To minimize the storage time the analysis was performed the day after collecting samples. Hydrochemical indications were made for each $10 \mathrm{~cm}$ section of core, which would provide detailed information about the variability of chemistry, taking place over time and at different levels of the vertical profile of snow cover. Sampling covered the period before and after the thaw episode, and the period of maximum thickness of snow cover. 


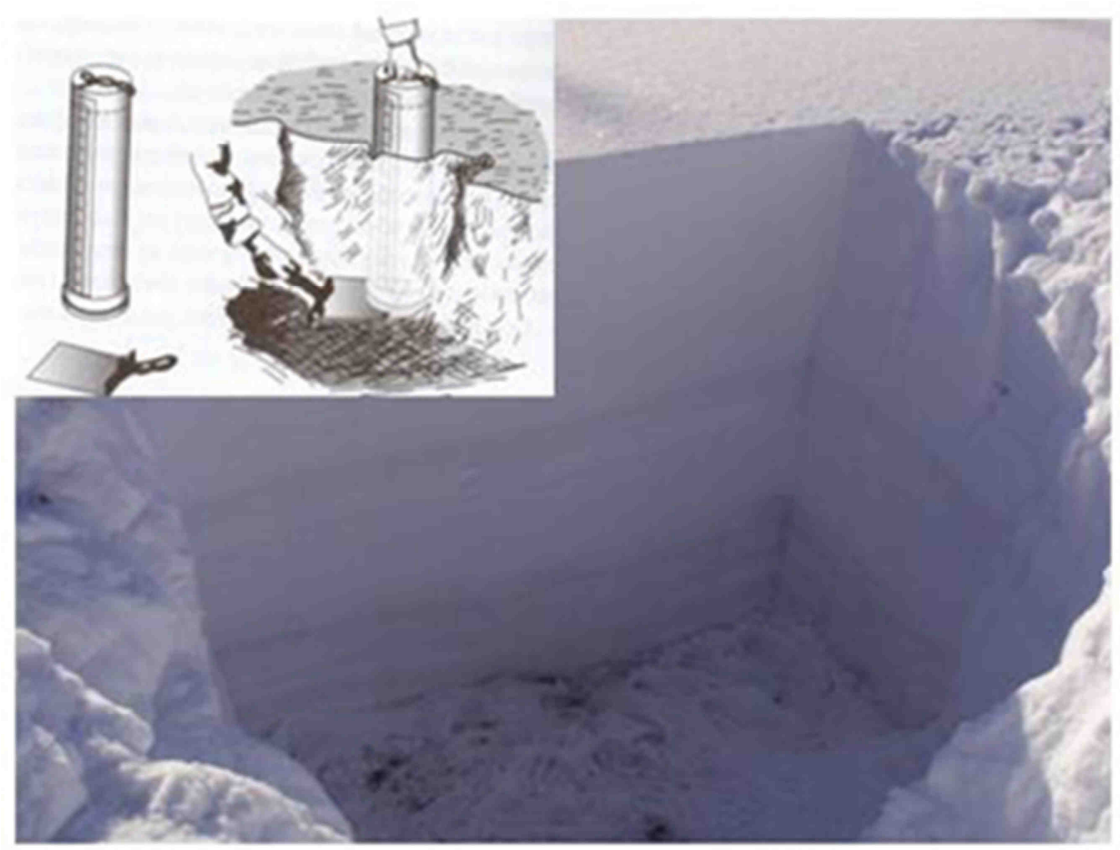

Fig. 2. Scheme and operation of the snow measuring cylinder [1]

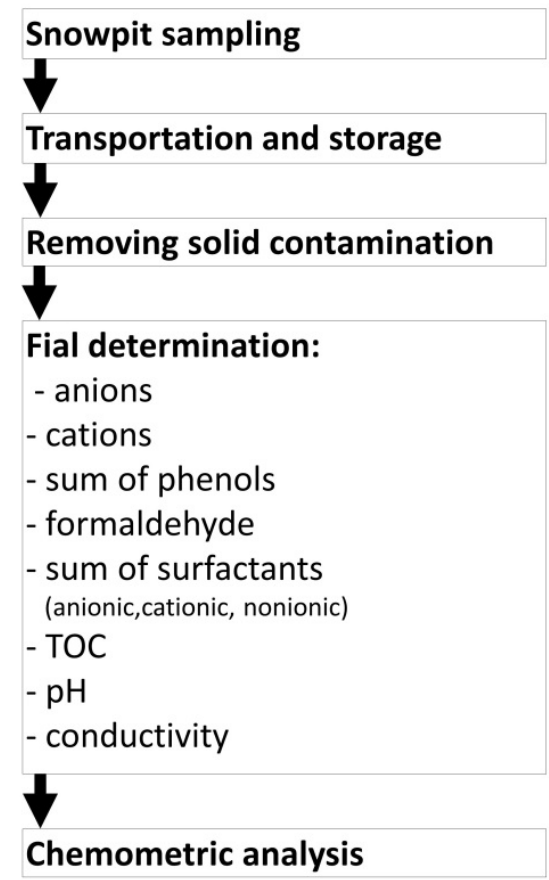

Fig. 3. Scheme of analytical procedure used to analyse snow samples 


\section{Analytical procedure}

With the aim of checking atmospheric pollution, samples were analyzed at the Gdansk University of Technology to measure levels of inorganic and organic compounds (Fig. 3). Ion chromatography Dionex - 500 and 3000 were used for determination of anions and cations (Dionex Corporation, USA). Selected anions and cations were quantified against synthetic rain standards: Reference Material No. 409 (BCR-409, Institute for Reference Materials and Measurements, Belgium) and Analytical Reference Material Rain-97 (National Water Research Institute, Environment Canada). Snowpit samples were analyzed on-site for $\mathrm{pH}$ and conductivity (Elmetron, Poland). Formaldehyde, sum of phenols, detergents (anionic, cationic, nonionic) were determined spectrophotometrically (SQ 118, PHARO 100, Merck, Germany). TOC was determined by using module CM 5300 Furnace Apparatus Version 1.0 (UIC INC.COULOMETRICS USA) and a coulometric detector (CM 5014 CO2 Coulometer).

All standards $\left(\mathrm{Mg}^{2+}, \mathrm{Ca}^{2+}, \mathrm{NH}_{4}^{+}, \mathrm{Na}^{+}, \mathrm{K}^{+}, \mathrm{SO}_{4}{ }^{2-}, \mathrm{NO}_{2}^{-}, \mathrm{NO}_{3}^{-}, \mathrm{F}^{-}, \mathrm{Cl}^{-}, \mathrm{Br}^{-}, \mathrm{PO}_{4}{ }^{3-}\right.$ $1000 \mathrm{mg} / \mathrm{dm}^{3}$ ), pyrophosphoric acid, sodium carbonate and anhydrous sodium carbonate were obtained from Merck (Darmstadt, Germany). Methanesulfonic acid was purchased from Sigma-Aldrich (Schnelldorf, Germany). Deionized water was obtained from the Milipore Gradient A10 (resistivity: $18.2 \mathrm{M} \Omega \cdot \mathrm{cm}$ at $25^{\circ} \mathrm{C}$ ) water purification system (Millipore, Bedford, MA, USA). The samples which contained suspended solids, were filtered on a $0.45 \mu \mathrm{m}$ PTFE filter for final determination. Figure 3 shows the diagram of sample preparation for analysis. Instrumentation used for the measurements, listed in Table 2, was selected to assure reliable and reproducible results.

Table 2

General characteristics of analytical techniques used in the studies

\begin{tabular}{|c|c|c|c|c|c|c|}
\hline $\begin{array}{l}\text { Analytical } \\
\text { method }\end{array}$ & Analyte & \multicolumn{3}{|c|}{ Analytical parameters } & $\begin{array}{c}\text { Limit of } \\
\text { detection }\end{array}$ & $\begin{array}{l}\text { Precision } \\
\text { [\% RSD] }\end{array}$ \\
\hline & & $\begin{array}{l}\text { Chromato- } \\
\text { graph type }\end{array}$ & \multicolumn{2}{|c|}{ DIONEX ICS3000 } & & \\
\hline & & & Anions & Cations & & \\
\hline \multirow{7}{*}{ IC } & \multirow{7}{*}{$\begin{array}{l}\text { Anions, } \\
\text { Cations }\end{array}$} & $\begin{array}{l}\text { Type of } \\
\text { column: }\end{array}$ & $\begin{array}{c}\text { Ion Pac } \mathrm{Pa}^{\circledR} \text { AS16 } \\
(3 \times 250 \mathrm{~mm})\end{array}$ & $\begin{array}{c}\text { Ion } \mathrm{Pac}^{\circledR}: \text { CS16 } \\
(3 \times 250 \mathrm{~mm})\end{array}$ & \multirow{7}{*}{$\begin{array}{c}\mathrm{F}^{-}, \mathrm{Br}^{-}= \\
0.01 \mathrm{mg} / \mathrm{dm}^{3} \\
\mathrm{Cl}^{-}= \\
0.06 \mathrm{mg} / \mathrm{dm}^{3} \\
\mathrm{NO}_{2}^{-}= \\
0.13 \mathrm{mg} / \mathrm{dm}^{3} \\
\mathrm{NO}_{3}^{-}= \\
0.014 \mathrm{mg} / \mathrm{dm}^{3} \\
\mathrm{PO}_{4}{ }^{3-}= \\
0.09 \mathrm{mg} / \mathrm{dm}^{3} \\
\mathrm{SO}_{4}{ }^{2-}= \\
0.05 \mathrm{mg} / \mathrm{dm}^{3} \\
\mathrm{Mg}^{2+}, \mathrm{Ca}^{2+}, \\
\mathrm{NH}_{4}^{+}, \mathrm{Na}^{+}, \\
\mathrm{K}^{+}= \\
0.01 \mathrm{mg} / \mathrm{dm}^{3}\end{array}$} & \multirow{7}{*}{1} \\
\hline & & $\begin{array}{l}\text { Eluent/ } \\
\text { flow rate: }\end{array}$ & $\begin{array}{c}1.4 \mathrm{mM} \mathrm{HCO}_{3}^{-} \text {and } \\
4.5 \mathrm{mM} \mathrm{CO}_{3}^{2-} ; \\
0.3 \mathrm{~cm}^{3} / \mathrm{min}^{-}\end{array}$ & $\begin{array}{c}30 \mathrm{mM} \mathrm{CH}_{3} \mathrm{SO}_{3} \mathrm{H} \\
0.3 \mathrm{~cm}^{3} / \mathrm{min}\end{array}$ & & \\
\hline & & Supressor: & $\begin{array}{c}\text { Self-Regenerating } \\
\text { Suppressor ASRS }^{\circledR} \\
300(2 \mathrm{~mm})\end{array}$ & $\begin{array}{c}\text { Self-Regenerating } \\
\text { Suppressor CSRS }^{\circledR} \\
300(2 \mathrm{~mm})\end{array}$ & & \\
\hline & & Detector: & \multicolumn{2}{|c|}{ Conductometric } & & \\
\hline & & $\begin{array}{l}\text { Sample } \\
\text { volume } \\
\text { injected: }\end{array}$ & $5 \mathrm{~mm}^{3}$ & $5 \mathrm{~mm}^{3}$ & & \\
\hline & & $\begin{array}{l}\text { Time of } \\
\text { analyse: }\end{array}$ & $16 \mathrm{~min}$ & $22 \mathrm{~min}$ & & \\
\hline & & Pressure: & 1700-2000 PSI & 1600-2000 PSI & & \\
\hline $\begin{array}{l}\text { Spectro- } \\
\text { photometry }\end{array}$ & $\begin{array}{l}\text { Sum of } \\
\text { phenols }\end{array}$ & \multicolumn{3}{|c|}{ Absorbency measured at $585 \mathrm{~nm}$} & $0.025 \mathrm{mg} / \mathrm{dm}^{3}$ & 5 \\
\hline & $\begin{array}{l}\text { Formal- } \\
\text { dehyde }\end{array}$ & \multicolumn{3}{|c|}{ Absorbency measured at $495 \mathrm{~nm}$} & $0.02 \mathrm{mg} / \mathrm{dm}^{3}$ & \\
\hline
\end{tabular}




\begin{tabular}{|c|c|c|c|c|}
\hline $\begin{array}{l}\text { Analytical } \\
\text { method }\end{array}$ & Analyte & Analytical parameters & $\begin{array}{r}\text { Limit of } \\
\text { detection }\end{array}$ & $\begin{array}{l}\text { Precision } \\
\text { [\% RSD] }\end{array}$ \\
\hline & Surfactants: & & & \\
\hline & \begin{tabular}{|l|} 
anionic \\
\end{tabular} & Absorbency measured at $650 \mathrm{~nm}$ & $0.05 \mathrm{~g} / \mathrm{dm}^{3}$ & \\
\hline & - cationic & Absorbency measured at $413 \mathrm{~nm}$ & $0.05 \mathrm{~g} / \mathrm{dm}^{3}$ & \\
\hline & - nonionic & Absorbency measured at $479 \mathrm{~nm}$ & $0.10 \mathrm{mg} / \mathrm{dm}^{3}$ & \\
\hline Coulometry & TOC & $\begin{array}{l}\text { High - temperature mineralization }\left(950^{\circ} \mathrm{C}\right) \text {, carrier gas - } \\
\qquad \mathrm{O}_{2} \text {, flow rate } 100 \mathrm{~cm}^{3} / \mathrm{min}\end{array}$ & $0.1 \mathrm{mg} \mathrm{C} / \mathrm{dm}^{3}$ & 2 \\
\hline \multirow[t]{2}{*}{$\begin{array}{l}\text { Electro- } \\
\text { chemical }\end{array}$} & $\mathrm{pH}$ & \multirow[b]{2}{*}{$\begin{array}{l}\text { Waterproof multi-function device CX-401 (electrode type } \\
\text { ESAgP-301W, a conductivity detector CD-2) }\end{array}$} & $\begin{array}{c}\mathrm{MR}^{*}: \\
0-14 \text { units }\end{array}$ & 5 \\
\hline & Conductivity & & $\begin{array}{c}\mathrm{MR}^{*}: \\
3.7-88.7 \\
\mu \mathrm{S} / \mathrm{cm}\end{array}$ & \\
\hline
\end{tabular}

"MR - Measuring Range

Data quality control was performed by evaluating the percentage difference of the ionic balance (PDI) and the sum of the total inorganic ionic content (TIC). PDI was calculated as [17]:

$$
\text { PDI }=\left(\text { Conc }_{\text {anions }}-\text { Conc }_{\text {cations }}\right) /\left(\text { Conc }_{\text {anions }}+\text { Conc }_{\text {cations }}\right)
$$

An acceptability criterion was set: PDI $\leq \pm 20 \%$. TIC represents the sum of liquid phase concentration of $\mathrm{SO}_{4}{ }^{2-}, \mathrm{NO}_{3}{ }^{-}, \mathrm{Cl}^{-}, \mathrm{H}^{+}, \mathrm{NH}_{4}{ }^{+}, \mathrm{Ca}^{2+}, \mathrm{Mg}^{2+}, \mathrm{Na}^{+}$and $\mathrm{K}^{+}$.

\section{Chemometric evaluation}

Chemometric techniques have been used in order to obtain information on multidimensional measurement data sets, concerning marking organic and inorganic compounds in snow samples and to facilitate the results visualisation [18, 19]. Snow samples collected in winter 2011/12 in all three measurement posts (Table 1, Fig. 1) have been analysed with the use of chemometric analysis. Samples were collected in 3 consecutive phases of snow cover development, i.e. stabilisation (Feb 1st), growth (Mar 15th) and its ablation (Mar 27th). The research does not comprise initial snowpack growth, which in the winter of 2011/12 was relatively short due to its over monthly delay and then its rapid increase at the beginning of December. To maintain a fixed number of samples, each snow profile has been divided into six layers. The fixed number of samples facilitated conducting chemometric analysis. In the samples the concentration of selected organic and inorganic compounds were marked according to the scheme presented in Figure 3.

The complete data set was subjected in the first run of chemometric data interpretation to:

Cluster Analysis - the method presents hierarchical grouping of the set of objects (trees) according to similarity of selected features;

$\checkmark$ Principal Components Analysis - the main objective of a chemometric approach, based on PCA technique is to detect an inner structure of measurements and its description with the use of parameters, factors or components resulting from the [18].

Further, self-organizing maps (SOM) - are a type of neural network describer by Kohonen [20] and used for visualization and interpretation of large high-dimensional data sets. SOM algorithm is a non-linear projection of the data from multi-dimensional "variable" space into discrete, usually two-dimensional array of neurons, also called nodes [21-23]. The projection is performed as each node in the grid is initialized as a random unit 
vector in n-dimensional space. Each object (sample in this study) from the data set is presented as n-dimensional input vector. Classification was used to distinguish between the different sites, variables, and phases constructing the data set - 3 sampling sites (each with 6 depths of sampling), 17 chemical variables, 3 phases of snowpack development (stabilisation, regrowth and ablation). Thus, the data set have dimension $54 \cdot 17$ objects. Chemical variables with analytical concentration below the LOD were treated as presented in concentrations LOD/2. It is important to mention that only chemical indicators were used in the chemometric interpretation (including conductivity measurements).

The major goal of the data mining was to find interpretable patterns in all modes of the data sets (sampling sites with depths, chemical variables and phases or time parameters). Additionally, the separate data sets for the three different sampling sites (Szrenica - S, Kamiennik - K, Orle - O) were examined for better understanding of possible hidden effects.

\section{Results and discussion}

\section{Clustering classification and Principal Components Analysis}

For each site (S, K, O) the hierarchical Ward's method of linkage [24], squared Euclidean distance as similarity measure, standardized raw data, cluster significance test according to Sneath's criterion clustering of the chemical variables was done (Fig. 4). Afterwards this grouping of the chemical variables was confirmed by the results from Principal Components Analysis (Table 3).

Clustering of the chemical variables on $\mathrm{S}$ site indicated formation of four clusters. $\mathrm{C} 1$ : $\mathrm{HARD}, \mathrm{Ca}, \mathrm{K}, \mathrm{pH}, \mathrm{Mg}, \mathrm{Cl}, \mathrm{Na}, \mathrm{F}$; C2: $\mathrm{SO}_{4}, \mathrm{NO}_{3}, \mathrm{NH}_{4}$; C3: $\mathrm{PHEN}, \mathrm{HCHO}$ (with higher distance to $\mathrm{PO}_{4}$ ); C4: $\mathrm{COND}, \mathrm{Br}, \mathrm{NO}_{2}$ (Fig. 4a, Table 3a). The sources of creation of the chemical composition are: "mineral salt", "secondary emission", "dissolved matter" and "oxidative" factor. The content of the clusters on $\mathrm{K}$ site differs from that of $\mathrm{S}$ site, indicating the various characters of possible sources (Fig. 4b). The results of the Principal Components Analyses for this site are presented in Table 3b. Slight differences in the number of chemical variables included in the identified sources was found both by cluster and principal components analyses on $\mathrm{O}$ site, but the general formation of four patterns was well documented. This is presented in the Figure $4 \mathrm{c}$ and in Table $3 \mathrm{c}$. The major cluster of $\mathrm{O}$ site is formed by the variables PHEN, $\mathrm{pH}, \mathrm{HCHO}, \mathrm{Mg}, \mathrm{K}, \mathrm{NH}_{4}, \mathrm{HARD}, \mathrm{Ca}, \mathrm{SO}_{4}$ and indicates the impact of a mixed source of "mineral salt" and "organic" influences. Again, a specific source of $\mathrm{PO}_{4}$ could be interpreted in the second cluster. The "dissolved matter" cluster is presented as $\mathrm{C} 3$ with the participation of $\mathrm{COND}, \mathrm{NO}_{3}, \mathrm{Cl}$. Instead of a well-defined "secondary emission" pattern (as in the previous two cases) an "oxidative" source $\left(\mathrm{Br}, \mathrm{NO}_{2}, \mathrm{~F}\right)$ appears. The specific dynamics of the chemical variables characterizing this sampling site is confirmed by the results from principal components analysis (Table $3 c)$. The identification of the latent factors responsible for the data set structure differs as compared to the clustering results. It means that the sources at $\mathrm{O}$ site are subject to more dynamic transformations in comparison to the situation at $\mathrm{S}$ and $\mathrm{K}$ sites.

Finally, all sites were treated as one data set. It was interesting to consider the complete set in order to understand if there is a clear separation between the sampling site, on one hand, or between the different phases of sampling, on the other one. 


\section{a)}

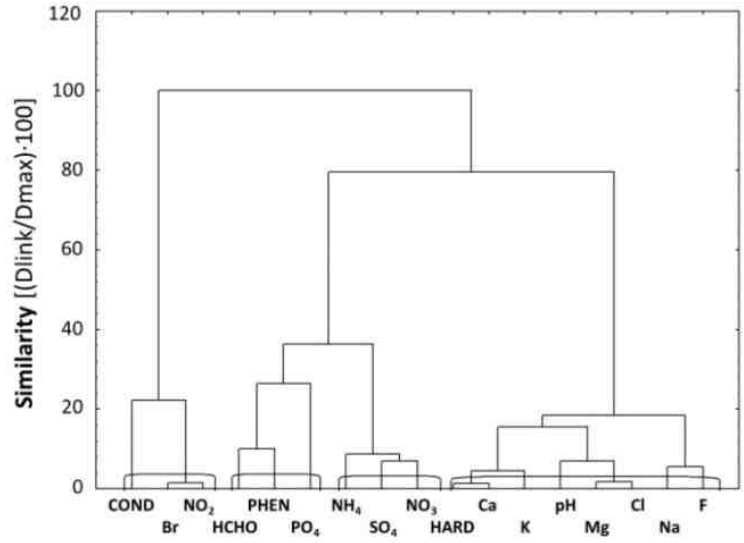

b)

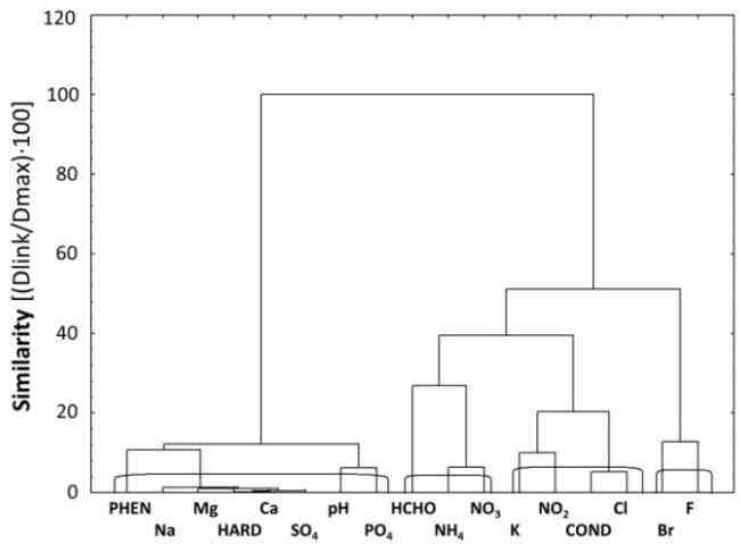

c)

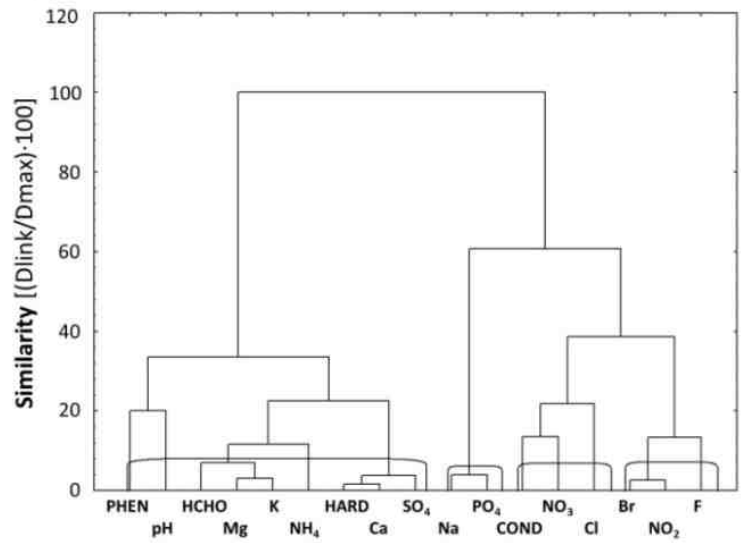

Fig. 4. Hierarchical dendrogram for 17 chemical variables (site: a) S, b) K, c) O) 
Factor loadings (Varimax normalized; significant loadings are highlighted)

\begin{tabular}{|c|c|c|c|c|c|c|c|c|c|c|c|}
\hline Variable & $\mathbf{F}$ & $\mathrm{Cl}$ & $\mathrm{NO}_{2}$ & $\mathbf{B r}$ & $\mathrm{NO}_{3}$ & $\mathrm{PO}_{4}$ & $\mathrm{SO}_{4}$ & $\mathbf{N a}$ & $\mathbf{K}$ & Mg & $\mathbf{C a}$ \\
\hline \multicolumn{12}{|c|}{ a) Szrenica (S) } \\
\hline PC 1 & 0.82 & 0.89 & -0.43 & -0.40 & -0.10 & -0.40 & 0.19 & 0.80 & 0.61 & 0.93 & 0.83 \\
\hline PC 2 & 0.18 & 0.13 & -0.31 & -0.40 & 0.92 & -0.06 & 0.91 & -0.06 & 0.52 & 0.06 & 0.37 \\
\hline PC 3 & -0.33 & 0.36 & -0.57 & -0.57 & 0.18 & 0.25 & -0.02 & -0.33 & 0.19 & 0.28 & -0.07 \\
\hline PC 4 & 0.06 & -0.02 & 0.53 & 0.56 & 0.04 & -0.56 & -0.11 & 0.37 & -0.35 & -0.01 & -0.18 \\
\hline \multicolumn{12}{|c|}{ b) Kamiennik (K) } \\
\hline PC 1 & -0.4 & 0.64 & -0.11 & -0.61 & -0.00 & 0.87 & 0.97 & 0.98 & -0.08 & -0.15 & 0.96 \\
\hline PC 2 & -0.05 & 0.6 & 0.81 & 0.23 & 0.04 & -0.06 & -0.02 & 0.12 & 0.21 & 0.86 & 0.04 \\
\hline PC 3 & -0.2 & 0.22 & -0.43 & -0.56 & 0.92 & -0.07 & 0.02 & 0.02 & 0.88 & 0.29 & 0.12 \\
\hline PC 4 & -0.60 & 0.07 & -0.04 & 0.10 & 0.22 & 0.15 & 0.11 & 0.03 & -0.05 & 0.24 & -0.03 \\
\hline \multicolumn{12}{|c|}{ c) Orle $(\mathrm{O})$} \\
\hline PC 1 & -0.19 & 0.12 & -0.27 & -0.28 & -0.4 & -0.07 & 0.88 & 0.07 & 0.38 & 0.91 & 0.73 \\
\hline PC 2 & 0.81 & 0.12 & 0.38 & 0.19 & 0.11 & -0.85 & -0.12 & -0.91 & 0.73 & 0.26 & 0.54 \\
\hline PC 3 & -0.36 & 0.21 & -0.83 & -0.85 & 0.12 & 0.11 & 0.16 & 0.10 & 0.27 & 0.29 & 0.26 \\
\hline PC 4 & -0.13 & 0.42 & 0.02 & -0.03 & 0.63 & -0.28 & 0.33 & 0.21 & 0.10 & -0.06 & -0.08 \\
\hline \multicolumn{12}{|c|}{ d) Szrenica, Kamiennik, Orle (S, K, O) } \\
\hline PC 1 & -0.11 & 0.71 & 0.00 & -0.35 & 0.02 & 0.45 & 0.87 & 0.90 & -0.03 & 0.18 & 0.92 \\
\hline PC 2 & -0.18 & -0.01 & -0.88 & -0.77 & 0.18 & 0.19 & 0.11 & -0.03 & 0.42 & 0.17 & 0.13 \\
\hline PC 3 & 0.81 & 0.32 & 0.06 & 0.02 & -0.10 & -0.52 & -0.22 & -0.39 & 0.49 & 0.48 & 0.21 \\
\hline PC 4 & -0.09 & 0.41 & 0.05 & -0.20 & 0.79 & -0.30 & 0.06 & -0.01 & 0.56 & 0.56 & 0.09 \\
\hline
\end{tabular}

\begin{tabular}{|c|c|c|c|c|c|c|c|}
\hline Variable & HARD & pH & COND & PHEN & $\mathbf{N H}_{4}$ & HCHO & Expl. Var. [\%] \\
\hline \multicolumn{8}{|c|}{ a) Szrenica (S) } \\
\hline PC 1 & 0.94 & 0.82 & -0.01 & -0.02 & 0.31 & 0.01 & 36.8 \\
\hline PC 2 & 0.25 & -0.09 & -0.05 & 0.25 & 0.66 & 0.02 & 17.4 \\
\hline PC 3 & 0.09 & 0.14 & 0.21 & 0.81 & 0.42 & 0.86 & 16.8 \\
\hline PC 4 & -0.11 & 0.06 & 0.83 & 0.14 & -0.04 & -0.07 & 11.4 \\
\hline \multicolumn{8}{|c|}{ b) Kamiennik (K) } \\
\hline PC 1 & 0.97 & 0.97 & 0.74 & 0.37 & 0.67 & 0.02 & 44.5 \\
\hline PC 2 & 0.09 & 0.07 & 0.52 & 0.78 & -0.01 & 0.01 & 16.3 \\
\hline PC 3 & -0.03 & 0.02 & -0.01 & 0.22 & 0.49 & -0.01 & 15.4 \\
\hline PC 4 & 0.15 & 0.10 & 0.05 & -0.17 & 0.38 & 0.86 & 8.7 \\
\hline \multicolumn{8}{|c|}{ c) Orle $(\mathrm{O})$} \\
\hline PC 1 & 0.85 & 0.93 & -0.09 & -0.04 & 0.16 & $\mathbf{0 . 8 1}$ & 29.2 \\
\hline PC 2 & -0.40 & -0.08 & 0.23 & -0.02 & 0.13 & 0.16 & 21.1 \\
\hline PC 3 & 0.26 & 0.30 & 0.24 & -0.51 & 0.86 & -0.02 & 18.2 \\
\hline PC 4 & 0.08 & 0.03 & -0.69 & 0.78 & -0.15 & -0.21 & 11.8 \\
\hline \multicolumn{8}{|c|}{ d) Szrenica, Kamiennik, Orle (S, K, O) } \\
\hline PC 1 & 0.96 & 0.97 & 0.58 & 0.45 & 0.10 & 0.04 & 33.5 \\
\hline PC 2 & 0.09 & 0.10 & 0.10 & -0.53 & 0.70 & 0.42 & 15.7 \\
\hline PC 3 & -0.04 & 0.04 & 0.57 & -0.17 & -0.14 & 0.32 & 13.1 \\
\hline PC 4 & 0.03 & 0.05 & -0.01 & 0.53 & 0.19 & 0.27 & 11.6 \\
\hline
\end{tabular}

The chemometric analysis should indicate if sampling depth plays any significant role in the data structure or the samples stay homogeneous irrespective of depth. Some information from the treatment of the separate data sets ( $\mathrm{S}, \mathrm{K}$ and $\mathrm{O}$ sites) proved that the phase separation is at hand but depth separation - not. Besides, the sides slightly differed with respect to the structure of the identified latent factors.

In Figure 5 the hierarchical dendrogram for the classification of the chemical variables is shown. Four well-defined clusters are formed: $\mathrm{C} 1: \mathrm{Na}, \mathrm{HARD}, \mathrm{Ca}, \mathrm{Mg}, \mathrm{SO}_{4}, \mathrm{PO}_{4}$; $\mathrm{C} 2$ : $\mathrm{PHEN}, \mathrm{HCHO}, \mathrm{NH}_{4}, \mathrm{NO}_{3}$; C3: $\mathrm{COND}, \mathrm{K}, \mathrm{pH}, \mathrm{Cl}$; C4: $\mathrm{Br}, \mathrm{NO}_{2}, \mathrm{~F}$. 


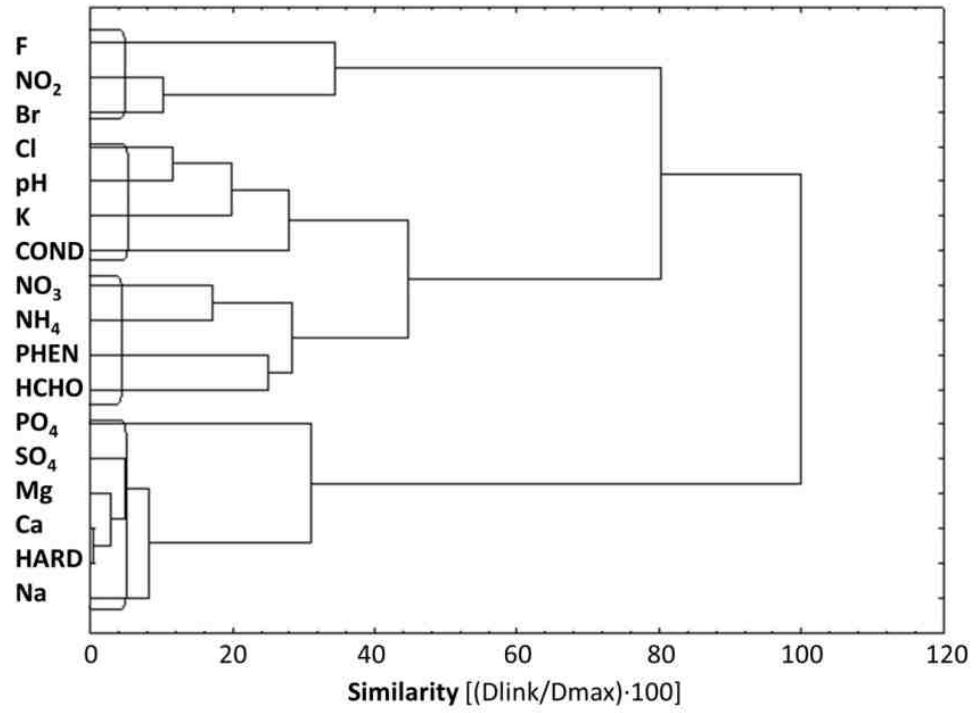

Fig. 5. Hierarchical dendrogram for 17 chemical variables (all sites: S, K, O)

It could be concluded that for the whole system of three sampling sites four patterns of variable groupings are observed: the first one is related to the "mineral salt" impact; the second one - with the impact of "secondary emissions" and "organic pollutants" (e.g. anthropogenic influence); the third one - with "dissolved matter" effect and the last one - with "oxidative" influence, again with relation to anthropogenic activities like smog, coal burning, traffic etc. This conclusion does not contradict the results obtained for the separate sampling sites (Fig. 4).

In general, similar conclusions could be drawn from the identification of the latent factors from the Principal Components Analysis (Table 3d). There is a slight distraction in the structure of the latent factors as compared to the results of clustering but, again, four significant latent factors explaining almost $75 \%$ of the total variance of the system could be interpreted as follows: PC 1 - "mineral salt" factor; PC 2 - "organic pollution" factor negatively correlated to "oxidative" effects; PC 3 - "mixed anthropogenic" factor reflecting various dynamics of a phosphate variable, potassium content and air pollution effects; PC 4 - "dissolved matter" factor - strongly correlated to "secondary emissions" impact.

The clustering of the objects (totally 18: 3 phases $\cdot 6$ depths of sampling) was also performed. The classification of the objects is of special interest in order to understand if time parameters and depth of sampling are important issues.

It has become instantly obvious that there are 4 patterns of objects formed for $\mathrm{S}$ site: $(1-6) ;(7,10-12,15,16)(8,9,18)$ and $(13,14,17)$. In the first cluster only samples from phase II (stabilization) are included; in the second and the third groups include dominant cases from phase III (re-growth) and the samples from phase IV (ablation) are included in clusters 2, 3, and 4 (Fig. 6a). This classification proves that the major discriminating factor for formation of the clusters is the phase but not the depth of sampling. It is also obvious that a clear separation of the objects with respect to three phases of sampling (real time dependence) is found for K site (Fig. 6b). 
a)

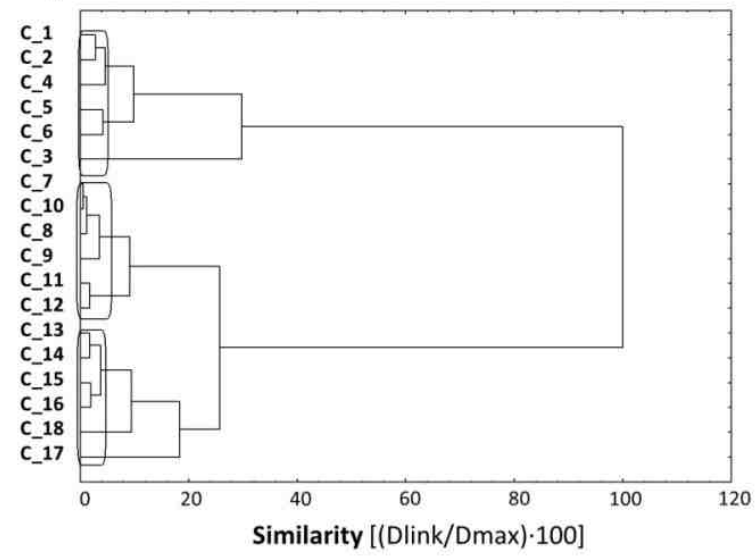

b)

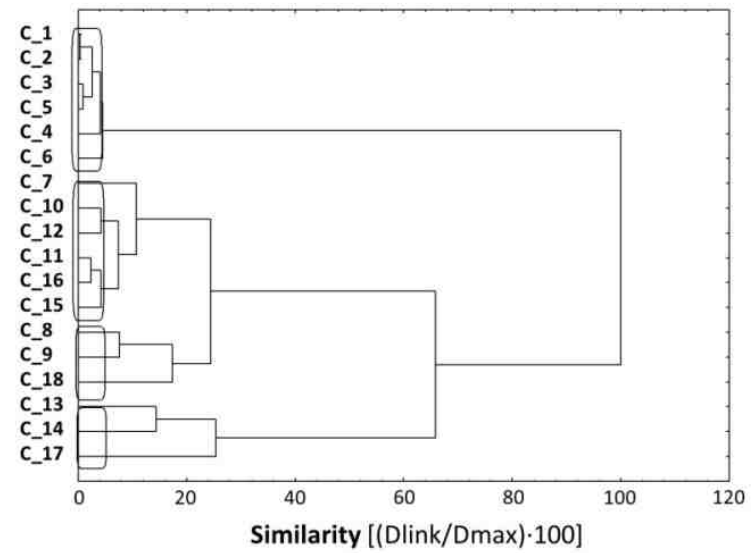

c)

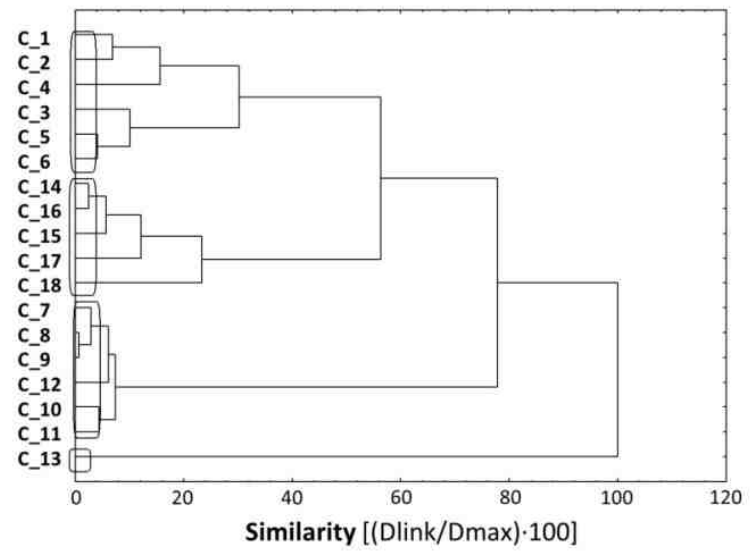

Fig. 6. Hierarchical dendrogram for clustering of objects (site: a) S, b) K, c) O) 
The depth of sampling does not play any significant role in this case (sample groups are homogeneous along the depth). There is no mixing of samples from different phases. Higher dynamics of the chemical sources does not influence the classification scheme of the samples on $\mathrm{O}$ site. As seen in Figure 6c the separation of the samples is in full accordance with the phase separation without depth influence. Sample 13 is the only outlier whose position is due to very high concentration levels of chemical variables forming PC 1 latent factor, i.e. very high mineral salt content and high level of HCHO.

Figure 7 shows clustering of all 54 samples from 3 sites, 3 phases and 6 depths. Four clusters are formed. The following samples are included in each cluster (represented by code - name of site, number of phase): C1: KII - 6 samples; C2: SII, SIV (12 samples), 2 samples KIV and 2 samples OIV - 16 samples; C3: OII, OIV (10 samples), 4 samples KIV 14 samples; C4: OIII (6 samples), KIII (6 samples), SII (6 samples) - 18 samples.

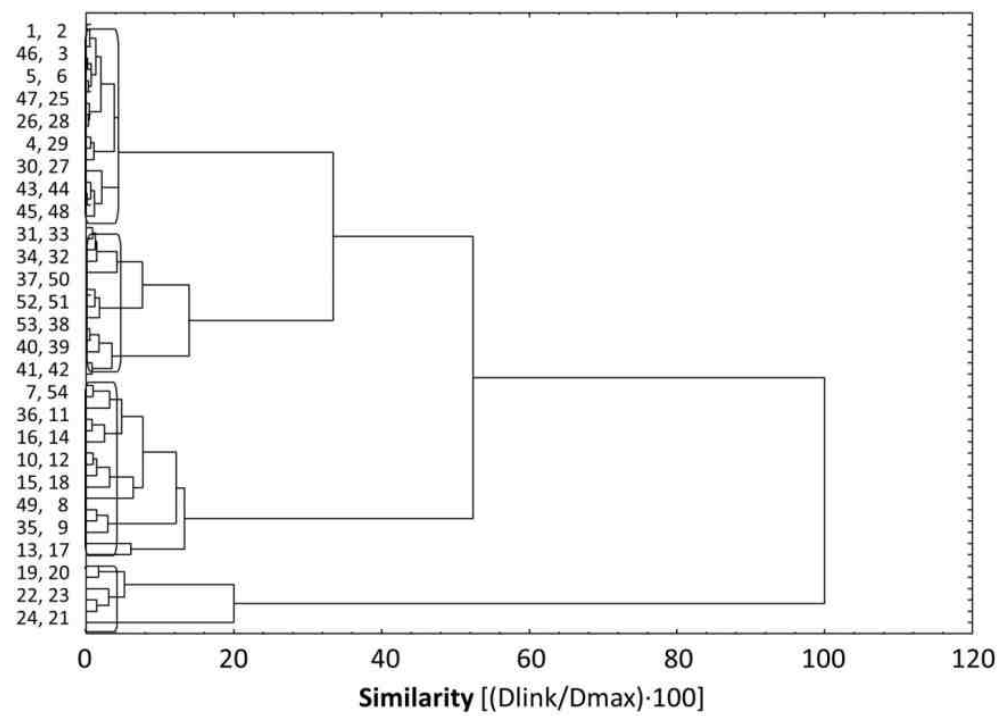

Fig. 7. Hierarchical dendrogram for clustering of objects (all sites)

As seen above, there is no distinct separation between sampling sites or between phases of observation (time factor). The content of the clusters is mixed. It may be assumed that the reason for some patterns of specificity is not related to the sampling site mode or phase (time) mode. In order to understand what the reason of clustering is discriminating variables for each cluster were determined. For each cluster the average values of the chemical parameters were calculated and compared to each other. In Table 4 the averages for each of the four clusters of objects are presented. Figure 8 illustrates the distribution of each parameter in each cluster. The analysis of the averages has indicated that cluster 1 is characterized by the highest levels of $\mathrm{Cl}, \mathrm{SO}_{4}, \mathrm{Na}, \mathrm{PO}_{4}, \mathrm{Mg}, \mathrm{Ca}, \mathrm{HARD}, \mathrm{COND}$. It means that the discriminating factor for the objects included in cluster 1 is the "mineral salt" pattern which is responsible for all samples KII. Additionally, the "dissolved matter" mode contributes $(C O N D)$ to this specificity. 
Average values of the chemical variables for each cluster

\begin{tabular}{|c|c|c|c|c|c|c|c|c|c|c|c|c|c|}
\hline \multirow{2}{*}{ Cluster } & $\mathbf{F}^{-}$ & $\mathbf{C l}^{-}$ & $\mathbf{N O}_{\mathbf{2}}^{-}$ & $\mathbf{B r}^{-}$ & $\mathbf{N O}_{\mathbf{3}}^{-}$ & $\mathbf{P O}_{\mathbf{4}}{ }^{3-}$ & $\mathbf{S O 4}^{2-}$ & $\mathbf{N a}^{+}$ & $\mathbf{N H}_{4}^{+}$ & $\mathbf{K}^{+}$ & $\mathbf{M g}^{2+}$ & $\mathbf{C a}^{2+}$ \\
\cline { 2 - 14 } & \multicolumn{10}{|c|}{$\left[\mathbf{m g} / \mathbf{d m}^{\mathbf{3}}\right]$} \\
\hline 1 & 0.055 & 1.244 & 0.083 & 0.023 & 0.441 & 0.724 & 4.789 & 2.502 & 0.148 & 0.025 & 0.410 & 1.404 \\
\hline 2 & 0.166 & 0.727 & 0.065 & 0.027 & 0.483 & 0.136 & 0.616 & 0.193 & 0.308 & 0.050 & 0.147 & 0.366 \\
\hline 3 & 0.049 & 0.338 & 0.065 & 0.029 & 0.339 & 0.554 & 0.668 & 0.692 & 0.143 & 0.014 & 0.055 & 0.241 \\
\hline 4 & 0.147 & 0.277 & 0.101 & 0.141 & 0.258 & 0.116 & 0.098 & 0.194 & 0.116 & 0.016 & 0.049 & 0.197 \\
\hline
\end{tabular}

\begin{tabular}{|c|c|c|c|c|c|}
\hline \multirow{2}{*}{ Cluster } & Total hardness & $\mathbf{p H}$ & Conductivity & Sum of phenols & HCHO \\
\cline { 2 - 6 } & {$\left[\boldsymbol{\mu e q} / \mathbf{d m}^{\mathbf{3}}\right]$} & {$[-]$} & {$[\boldsymbol{\mu S} / \mathbf{c m}]$} & {$\left[\mathbf{m g} / \mathbf{d m}^{\mathbf{3}}\right]$} & {$\left[\mathbf{m g} / \mathbf{d m}^{\mathbf{3}}\right]$} \\
\hline 1 & 0.104 & 5.987 & 13.029 & 0.133 & 0.058 \\
\hline 2 & 0.031 & 5.680 & 6.876 & 0.152 & 0.090 \\
\hline 3 & 0.017 & 5.083 & 7.341 & 0.157 & 0.036 \\
\hline 4 & 0.014 & 5.212 & 8.996 & 0.017 & 0.045 \\
\hline
\end{tabular}

a)

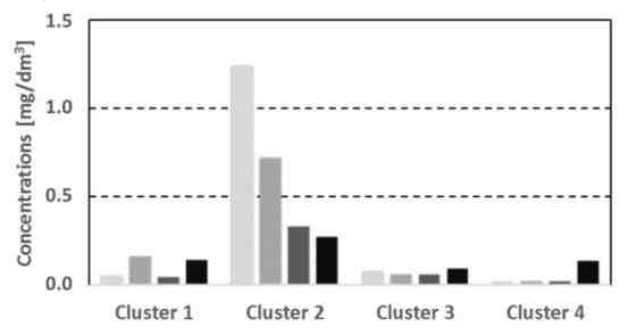

c)

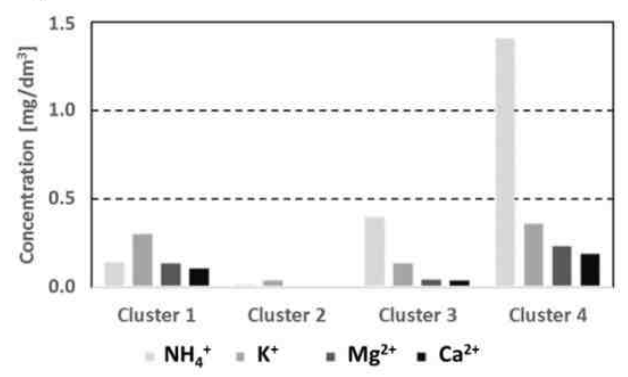

e) b)

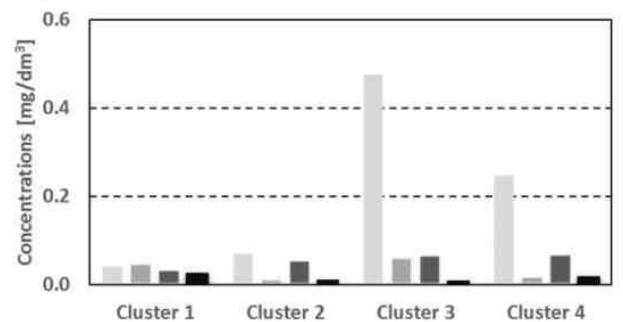

d)
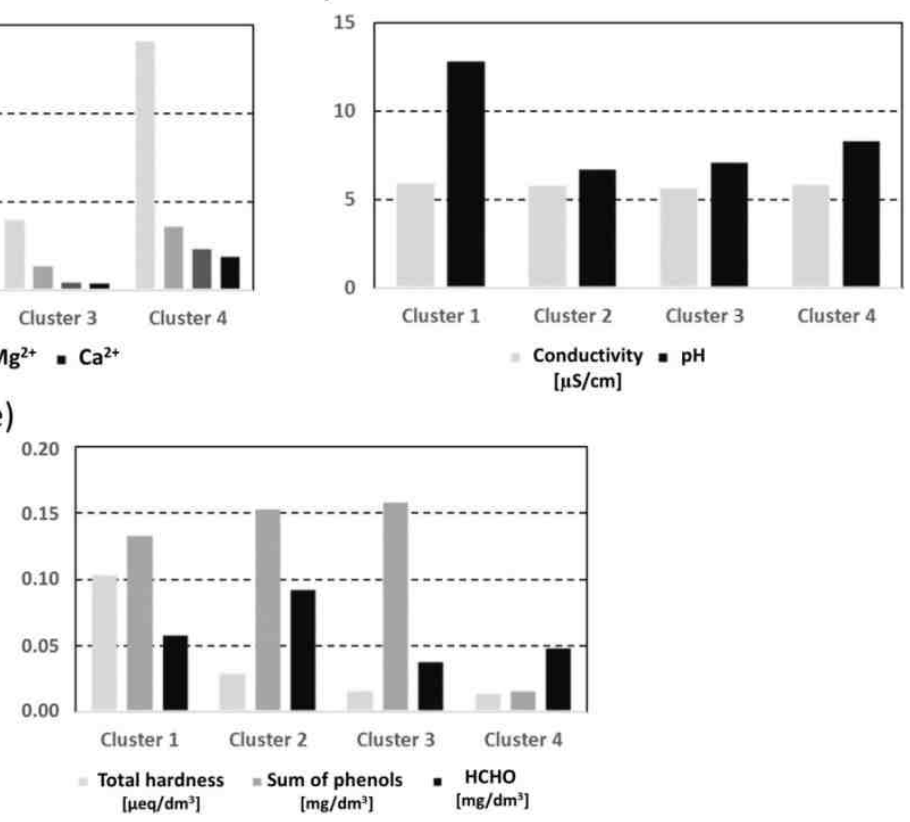

Fig. 8. Average values of chemical variables in particular group diagrams 
Cluster 2 is characterized by the highest concentration levels of $\mathrm{F}, \mathrm{NH}_{4}, \mathrm{~K}, \mathrm{NO}_{3}$, HCHO, PHEN which indicates a combined effect of "secondary emissions" and "anthropogenic impact" modes on the samples in cluster 2 . It is likely that these samples reflect an environmental state with enhanced level of pollution. Cluster 3 is marked by the lowest levels of all chemical parameters and it is an indication that $\mathrm{O}$ site is relatively the cleanest one. This is a "benchmark" mode. Cluster 4 involved samples with the highest concentrations of $\mathrm{Br}, \mathrm{NO}_{2}$. Therefore, a discriminating pattern is the "oxidative impact". Finally, it might be concluded that the specificity of the samples is determined by the factors responsible for the data set structure and not by particular individual or time factors. Thus, the application of multi-way principal components analysis will not provide adequate models.
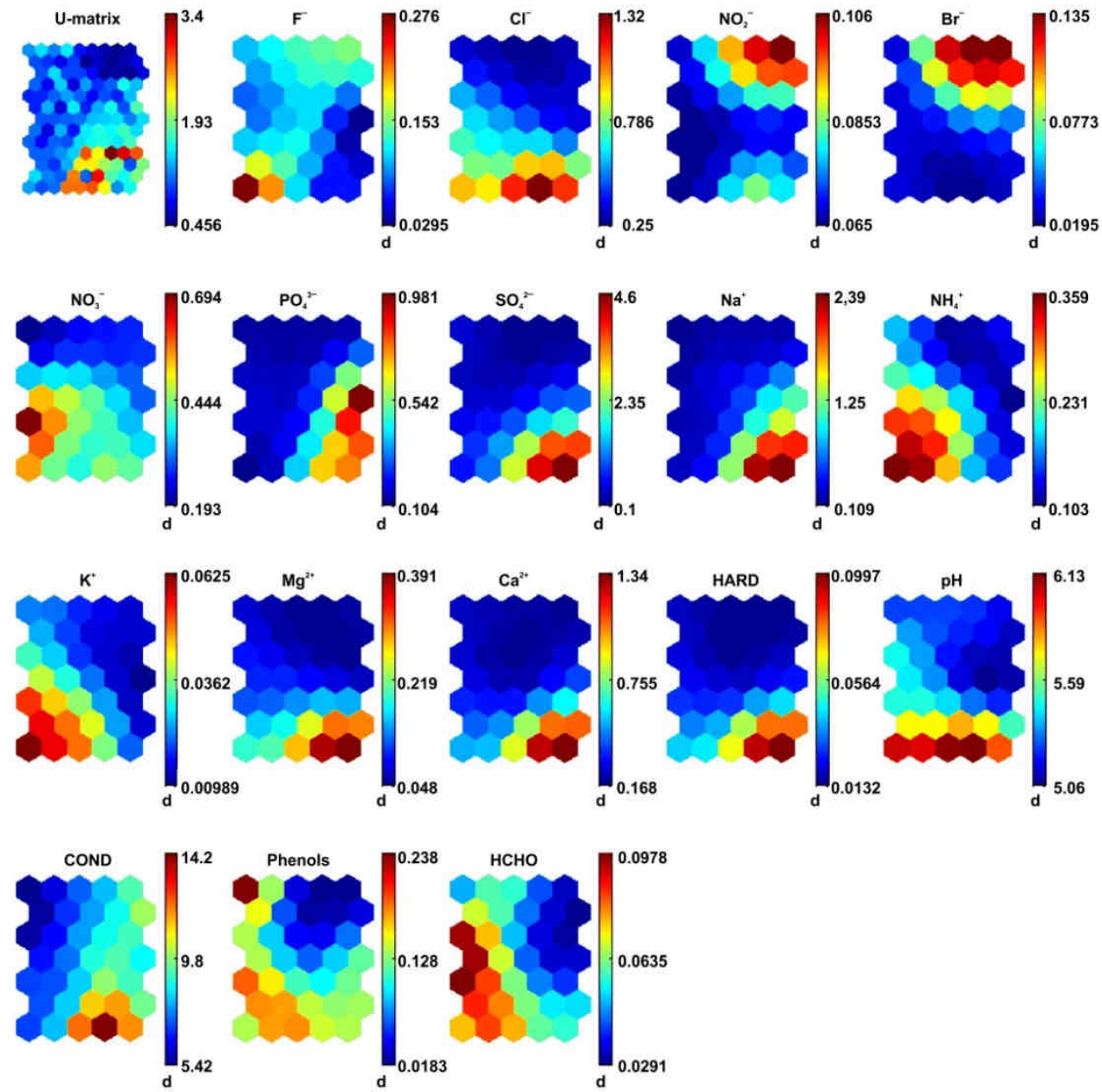

Fig. 9. Self-organizing maps of Kohonen (all samples, all variables) 


\section{SOM classification}

The data set containing all data $(54 \cdot 17$ objects) was further subjected to classification using self-organizing maps. Due to some advantages of the method it can be applied as validation scheme for the classifications and models obtained by using cluster and principal components analysis [21-23]. In Figure 9 the maps of all sites and all variables are given.

Similar patterns of distribution can be instantly observed for the variables $\mathrm{PO}_{4}, \mathrm{SO}_{4}$, $\mathrm{Na}, \mathrm{Mg}, \mathrm{Ca}, \mathrm{HARD}, \mathrm{Cl}$ (high levels of concentration in the right down corner); then for $\mathrm{NO}_{2}, \mathrm{Br}$ (high levels of concentration in the right upper corner); slighter resemblance can be also detected for PHEN, $\mathrm{HCHO}$ and between $\mathrm{NH}_{4}, \mathrm{NO}_{3}$ or between $\mathrm{pH}$, COND; $\mathrm{K}$ matches $F$. In general, it confirms the formation of the variable linkage of the previous two chemometric classifications, i.e. formation of "mineral salt", "oxidative", "secondary emissions", "dissolved matter", "organic pollution" impacts.

\section{Conclusions}

Snow cover is a highly dynamic medium. Both physical and chemical processes can cause a change in its chemical composition, so comprehensive tests should be carried out to ascertain the contaminant content in snow. The chemical composition of snow layers reflects the composition of native atmospheric aerosols, dry precipitation and the nature of an adsorbent surface. The accumulation of components in snow cover, present in the atmosphere, depends on the weather and on the properties of the surface covered in snow. The chemical composition of snow can provide a great deal of useful information on the levels of contaminants in the atmosphere, changes in these levels over time, and mechanisms of their transport and deposition.

The major conclusion from the chemometric data interpretation is as follows: the latent factors responsible for the data structure (both for each separate sample site and for all together) are, in principle, the same: mineral salt, secondary emissions, dissolved matter, organic pollution, oxidative. They alone, but not spatial or time (phase) factors, contribute to the separation of the samples into different patterns. It has been convincingly proven that no need for multiple principal components analysis is needed to interpret the results obtained.

\section{Acknowledgements}

This work was supported by the Polish National Science Centre grant (2012/05/B/ST10/00437 and N N305 373438).

\section{References}

[1] Davidson CI, Santhanam S, Fortmann RC, Olson MP. Atmospheric transport and deposition of trace elements onto the Greenland ice sheet. Atmos Environ. 1985;19:2065-2081. DOI: 10.1016/0004-6981(85)90115-5.

[2] Hidy GM. Snowpack and precipitation chemistry at high altitudes. Atmos Environ. 2003;37:1231-1242. DOI: 10.1016/j.jhydrol.2011.09.007.

[3] Dossi C, Ciceri E, Giussani B, Pozzi A, Galgaro A, Viero A, et al. Water and snow chemistry of main ions and trace elements in the karst system of Monte Pelmo massif (Dolomites, Eastern Alps, Italy). Mar Freshwater Res. 2007;58(7):649-656. DOI: 10.1071/MF06170.

[4] Colbeck SC. Theory of metamorphism of dry snow. J Geophys Res. 1983;88(19):5475-5482. DOI: 10.1029/JC088iC09p05475. 
[5] Lee J, Nez VE, Feng X, Kirchner JW, Osterhuber R, Renshaw CE. A study of solute redistribution and transport in seasonal snowpack using natural and artificial tracers. J Hydrol. 2008;357(3):243-254. DOI: 10.1016/j.jhydrol.2008.05.004.

[6] De Rosemond S, Duro DC, Dubé M. Comparative analysis of regional water quality in canada using the water quality index. Environ Monit Assess. 2009;156(1-4):223-240. DOI: 10.1007/s10661-008-0480-6.

[7] Turk JT, Taylor HE, Ingersoll GP, Tonnessen KA, Clow DW, Mast MA, et al. Major-ion chemistry of the Rocky Mountain snowpack, USA. Atmos Environ. 2001;35:3957-3966. DOI: 10.1016/S1352-2310(01)00189-3.

[8] Singh P, Singh VP. Snow and Glacier Hydrology. Water Science and Technology, Kluwer Academic Publishers, 2001; .756. http://www.springer.com/us/book/9780792367673.

[9] Chang K, Li Z. Modeling snow accumulation with a geographic information system. Int J Geogr Inf Sci. 2000;14(7):693-707. DOI: 10.1080/136588100424981.

[10] Błaś M, Cichała-Kamrowska K, Sobik M, Polkowska Ż, Namieśnik J. Conditions controlling atmospheric pollutant deposition via snowpack. Environ Rev. 2010;18:87-114. DOI: 10.1139/A10-003.

[11] Colbeck SC. A simulation of the enrichment of atmospheric pollutants in snow cover runoff. Water Resour Res. 1981;17(5):1383-1388. DOI: 10.1029/WR017i005p01383.

[12] Dore AJ, Sobik M, Migała K. Patterns of precipitation and pollutant deposition by rain and snow in the western Sudetes Mountains, Poland. Atmos Environ. 1999;33:3301-3312. DOI: 10.1016/S1352-2310(98)00294-5.

[13] Kozłowski R, Jóźwiak M, Jóźwiak M, Rabajczyk A. Chemism of atmospheric precipitation as a consequence of air pollution: the case of Poland's holy cross mountains. Polish J Environ. 2011;4:919-924. www.pjoes.com/abstracts/2011/Vol20/No04/13.html.

[14] Zimmermann F, Matschullat J, Bruggemann E, Pleßow K, Wienhaus O. Temporal and elevation related variability in precipitation chemistry from 1993 to 2002, Eastern Erzgebirge, Germany. Water Air Soil Pollut. 2006;170:123-141. DOI: 10.1007/s11270-006-2860-2.

[15] Tsakovski S, Tobiszewski M, Simeonov V, Polkowska Ż, Namieśnik J. Chemical composition of water from roofs in Gdansk, Poland. Environ Pollut. 2010;58:84-91. DOI: 10.1016/j.envpol.2009.07.037.

[16] Simeonov V, Simeonova P, Tsakovski S, Lovchinov V. Lake water monitoring data assessment by multivariate statistics. J Water Resource Prot. 2010;2:353-361. DOI: 10.4236/jwarp.2010.24041.

[17] Cini R, Prodi F, Santachiara G, Porcu F, Bellandi S, Stortini AM, et al. Chemical characterization of cloud episodes at a ridge site in Tuscan Appennines. Atmos Res. 2002;61:311-334. DOI: 10.1016/S0169-8095(01)00139-9.

[18] Stanimirova I, Walczak B, Massart DL. Multiple factor analysis in environmental chemistry. Anal Chim Acta. 2005;545:1-12. DOI: 10.1016/j.aca.2005.04.054.

[19] Mellinger M. Chemometr Intell Lab Syst. 1987;2(29):29-36. DOI: 10.1016/0169-7439(87)80083-7.

[20] Kohonen T. Self-organizing Maps. Berlin: Springer; 2001. www.springer.com/cn/book/9783540679219.

[21] Jin H, Shum WH, Leung KS, Wong ML. Expanding self-organizing map for data visualization and cluster analysis. Inf Sci. 2004;163:157-173. DOI: 10.1016/j.ins.2003.03.020.

[22] Cavazos T. Using self-organizing maps to investigate extreme climate events: An application to wintertime precipitation in the Balkans. J Clim. 2000;13:1718-1732. DOI: 10.1175/1520-0442(2000)013<1718:USOMTI>2.0.CO;2.

[23] Fassnacht SR, Derry JE. Defining similar regions of snow in the Colorado River Basin using self-organizing maps. Water Resour Res. 2010;46:W04507. DOI: 10.1029/2009WR007835.

[24] Ward JH. Jr. Hierarchical grouping to optimize an objective function. J Amer Stat Assoc. 1963;58:236-244. DOI: 10.1080/01621459.1963.10500845. 